\title{
Using micro-morphological fruit characters in resolving some of ambiguities in Iranian Acer L. (Sapindaceae) species
}

\author{
FATEMEH ASADI, FARIBA SHARIFNIA ${ }^{\natural}$, FAHIMEH SALIMPOUR, AHMAD MAJD \\ Department of Biology, Tehran North Branch, Islamic Azad University. Pasdaran, Makran St. Boostan 9th, Tehran 1948664517, Iran. \\ P.O. Box: 19585-936. `email: fa.sharifnia@gmail.com
}

Manuscript received: 11 October 2018. Revision accepted: 29 December 2018.

\begin{abstract}
Asadi F, Sharifnia F, Salimpour F, Majd A. 2019. Using micro-morphological fruit characters in resolving some of ambiguities in Iranian Acer L. (Sapindaceae) species. Biodiversitas 20: 297-304. Acer L. belongs to the Sapindaceae family consists of 126 species which are distributed in the temperate regions of the northern hemisphere. There are 12 taxa (including Acer monspessulanum with four subspecies and Acer velutinum with two varieties) in Iran. In this study 21 fruit characteristics are partially investigated using Scanning Electron Microscope (SEM) and Stereomicroscope. According to the obtained results, four types of faveolate, folded, wrinkled and pavement wing surface ornamentations as well as four types of faveolate, folded, verrucous, and wrinkled achene surface ornamentations were observed. Hair of wing margin, achene hair, wing ornamentation, inside angle of wing, and outside angle of wing have taxonomic value. According to fruit morphology, separation of 4 subspecies of A. monspessulanum can be verified. Also varieties of A. velutinum var. velutinum, and A. velutinum var. glabrescens were totally separated due to differences in characteristics such as wing ornamentation, achene ornamentation, hair density of achene, wing length, wing width, the ratio of length to width of wing, total fruit length, total fruit width, the ratio of length to width of fruit, inside angle of wing, outside angle of wing. The results showed that micro-morphological fruit characters of Acer genus are valuable in terms of taxonomy and classification of subspecies level.
\end{abstract}

Keywords: Acer, Iran, micromorphology, subspecies

\section{INTRODUCTION}

Sapindaceae including. Aceraceae-Hypocastanaceae with 131-135 genus (Xu et al. 2008; Simpson 2010) is distributed mainly in moderate regions. Acer is one of the largest genera of this family and it is distributed in Asia, Europe, North America and North of Africa. At present, approximately 200 maple species are known, half of which occurs in China. Within this genus, polyploid species occur and the number of cultivated species derived from various genotypes of Acer in terms of ploidy amounts to over 600 (Van Gelderen et al. 1994; Hasebe et al. 1998). The genus is easily recognized by opposite leaves and samaras fruit. However, other morphological characters are highly diversified. Due to morphological diversity, many varieties and forms were generated that makes the genus taxonomically very difficult (Delendick 1990; Park et al. 1993; Judd et al. 2002). The arrangement of the two and seldom three winged pericarps (samaras) are seen in this genus and they have ranged from subparallel to diverging at about a right angle. A number of characters that are beneficial for identification of species in the field may have evolved independently (lobe shape leaves and margin of leaves lobes). These traits may be highly variable within species like pubescence of lower leaf surface (Grimm et al. 2007). Several different florescence types, including racemes, panicles, corymbs and spikes, occur in this genus. These variations make infrageneric divisions very difficult. Species delimitation and phylogenic relationships within the genus Acer are also very controversial (Kholie 1967;
Judd et al. 2002).

Classification and phylogenic relations of Acer species have always been questionable and different categorizations on sections or series have been proposed (Pax 1902; Pojarkova 1933; Momotani 1962; Fang 1966; Ogata 1967; Murray 1970; De Jong 1976; Tanai 1978; Van Gelderen et al. 2010; Weakley 2011). Fang (1966) proposed a different system in which the genus was divided into two subgenera, mainly on the basis of simple versus compound leaves. In Ogata's system (Ogata 1967), the genus was classified into 26 sections In 1970, Murray published his monograph of the Aceraceae with 7 subgenera, 24 sections and 35 series within Acer (Murray 1970). Ogata's system was essentially followed by Xu (1966), with some additions and amendments. More recently De Jong (1994) recognized only 19 series in 16 sections, providing a quite different arrangement from those of other authors (Pax 1902; Xu 1966, 1998; Ogata 1967; Xu et al. 2008). In recent classifications, Acer consists of 16 sections and 126 species (AcevedoRodringuez et al. 2011). There are so high hybridization and diversity between Acer species that taxonomic identification is difficult (Grimm et al. 2007, 2014). Interand intraspecific variability of the group is the main cause of its taxonomic complexity. In addition, with hybridization as a potentially effective phenomenon in the formation of species complexes, it is difficult to identify species of maples (Grimm et al. 2007). Characterizing the new sequence types, Grimm and Denk (2014) showed that cryptic speciation can occur in isolated populations of 
maples and reported cryptic species in maples from Georgia. Cytogenetic studies of Acer, which has a basic chromosome number of $13(\mathrm{x}=13)$ and various levels of ploidy (Grimm and Denk 2014), confirms inter-and intraspecific complications in the genus. According to different sources, eight species of Acer, i.e., A. hyrcanum, A. cappadocicum, A. campestre, A. monspessulanum, A. platanoides, $A$. velutinum $A$. mazandaranicum, and $A$. tataricum are distributed in Iran (Murray 1969; Maroofi and Sharifi 2006; Amini et al. 2008). According to Buerki et al. (2009), these taxa are classified in three sections: Sec. Acer (A. mazandaranicum, A. hyrcanum, A. velutinum, A. monspessulanum), Sec. Platanoidae (A. campestre, A. cappadocicum, A. platanoides), and Sec. Ginalla (A. tataricum). Alborz and Zagros mountains are main centers of this generic distribution in Iran.

A. monspessulanum $\mathrm{L}$. is the unique species that appears a medium-sized deciduous tree or densely branched shrub that grows to a height of 10-15 m (rarely to $20 \mathrm{~m}$ ) (Fontaine 2011). The trunk is up to $75 \mathrm{~cm}$ diameter, with smooth, dark grey bark on young trees, becoming finely fissured on old trees. Among similar maple is easily distinguished by its small three-lobed leaves, 3-6 cm long and 3-7 cm wide, glossy dark green, sometimes a bit leathery, and with a smooth margin, with a $2-5 \mathrm{~cm}$ petiole. The leaves fall very late in autumn, typically in November. The flowers are produced in spring, in pendulous, yellow to white corymbs 2-3 cm long. The samaras are $2-3 \mathrm{~cm}$ long with rounded nutlets (Rushforth 1999, Van Gelderen 1999). Acer monspessulanum from Acer section (Van Gelderen et al. 1994) has distinct small, 3-lobed leaves, while its close relatives $A$. hyrcanum and $A$. opalus normally have 5-lobed leaves.

Acer monspessulanum fossils are fairly common in Late Miocene and Pliocene floras from southern Europe and south-western Asia (Kvacek et al. 2002; Sachse 2004). A. monspessulanum $\mathrm{L}$. is the unique species that appears a small tree and it is very complicated (incl. A. assyriacum Pojark., A. cinerascens Boiss., A. persicum Pojark. and A. microphyllum (Boiss.) Dinsm). Now, these species are treated as subspecies. Meanwhile, they are very similar to each other. This species has a large number of subspecies and varieties, most of them are not accepted because they are variations affected by environmental conditions (Amini et al. 2008). On the other hand, there are similarities between A. mazandaranicum and A. hyrcanum, especially in leaves characters. And so, there are some doubts about A. velutinum and A. cappadocicum varieties. According to Russian flora Acer velutinum or velvet maples are endemic of Caucasus (Iran has two varieties) and tall trees with even trunk and broad crown, up to $40 \mathrm{~m}$ high, $1.2 \mathrm{~m}$ in diameter; bark gray, juvenile shoots reddish-brown, glabrous; leaves up to $30 \mathrm{~cm}$ long and wide, averagely $13-15 \mathrm{~cm}$, dark green above, always glabrous, paler beneath, glabrous (var. glabrescens Boiss. et Buhse, var. van volxemii (Mast.) Pax) or completely velutinous-hairy beneath (var. velutinum Boiss. et Buhse), usually cordate, rarely more or less rounded or truncate at base, always 5 lobed, the three upper lobes ovate, acute. The flower panicles are longpedunculated, erect, dense, up to $5 \mathrm{~cm}$ long, with hairy axes and bracts. The sepals are oblong-ovate; petals narrow, slightly longer. The sepals and petals are hairy inside. The flowers are small, greenish-yellow. The fruiting panicle has almost 60 samaras, wings tapering at the base, then rounded above, diverting at a right angle. Flowering from April to May. Fruiting in August. The trees are found in damp tertiary relict forests, usually as sparse trees, rarely in small groups, growing together up to $1700 \mathrm{~m}$ (Pojarkova 1949).

It seems that the micro-morphological characters could be useful for taxonomic separation of close taxa. (Gran and Sharifnia 2008; Sharifnia et al. 2009; Sharifnia and Behzadi Shakib 2012; Bani et al. 2016). Some researchers discussed the infrageneric phylogenetic relationships in the genus by analyzing gross morphology, seed proteins, fossils and geographic distributions, but the conclusions were not in consensus (Momotani 1962; Rechinger 1969; Pax 1985, 1986; Wolfe and Yanai 1987; Thorne 1992).

Variation in fruits characters of Acer is crucial for separating the similar taxa. The aim of this study was to investigate micro-morphological data of fruits for evaluation and taxonomic implications of Iranian Acer species.

\section{MATERIALS AND METHODS}

Samara fruits of 12 samples of Acer taxa were investigated here (Table 1). Samples are kept in the herbarium of Islamic Azad University, Tehran North Branch (IAUNT). 21 quantitative and qualitative (bi-state as 0 and 1 or sometimes three state 0,1 and 2) characteristics of the fruits such as shape of wing ornamentation (SWO), wing ornamentation (WO), shape of achene ornamentation (SAO), presence or absence of openings on achene surface (AS), hair density of achene (HAD), wing angle (WA), outside angle of the wing (OAW), inside angle of the wing (IAW), and ratio of inside angle of the wing to outside angle of the wing (IAW/OAW) (investigated traits in table 2). The characteristics were investigated with BEL stereomicroscope model STMRO-B and as for micro-morphological study, the wing of fruits was stabled on the aluminum Stub and was covered by golden coat after freezing. Samples were observed via Scanning Electron Microscope (SEM) (EM 3200). Clustering analysis was performed according to Unweighted Pair Group Method with Arithmetic ( UPGMA) method; the UPGMA algorithm constructs a rooted tree (dendrogram) that reflects the structure present in a pairwise similarity matrix (or a dissimilarity matrix). At each step, the nearest two clusters are combined into a higher-level cluster. The data of characters were standardized before analyzing, finally, factor analysis and principal component analysis (PCA) have been done (Podani 2000).

\section{RESULTS AND DISCUSSION}

According to the obtained results, four types of faveolate, folded, wrinkled and pavement wing surface 
ornamentations as well as four types of faveolate, folded, verrucous, and wrinkled achene surface ornamentations were observed (Figure 2-3). Based on the results obtained from analyzing 12 samples, the ratio of inside angle of the wing to outside angle of the wing varies from 1 ( $A$. campestre) to 4 (A. monspessulanum subsp. Persicum); fruit length varies from $1.5 \mathrm{~cm}$ (A. monspessulanum subsp. microphyllum, A. monspessulanum subsp. persicum) to 4.5 $\mathrm{cm}$ (A. velutinum var. glabrescens); the longest wing belonged to $A$. velutinum var. glabrescens while the shortest wing belonged to A. platanoides; the widest wing was observed in A. mazandaranicum. In order to study the fruit, phenotypic similarities cluster analysis showed two major clusters: Cluster A consisted of section Platanoidae (A. platanoides, A. campestre, A. cappadocicum var. stenocarpum, A. cappadocicum, var. cappadocicum) and cluster B included the species of section Acer ( $A$. mazandaranicum, A. hyrcanum, A. velutinum var velutinum, $A$. velutinum var. glabrescens, $A$. monspessulanum subsp. microphyllum, A. monspessulanum subsp. cinerascens, A. monspessulanum subsp. assyriacum, A. monspessulanum subsp. persicum) ( Figure 1)

According to Dendrogram cluster A consist of. A. platanoides (A1) and A. campestre, A. cappadocicum var. cappadocicum, A. cappadocicum var. stenocarpum (A2). Wing ornamentation arrangement, achene surface arrangement, the ratio of length to width of wing, total fruit length, inside angle of wing, and the ration of inside angle of wing to outside angle of wing are the main characters in them. Also, varieties of A. cappadocicum were separated from A. campestre in A2 cluster. At taxonomic distance of 2 , which shows that some characteristics such as wing ornamentation, type of wing and achenes ornamentation are important separating of $A$. cappadocicum varieties. Cluster $\mathrm{B}$ is divided into two sub-clusters. Sub-cluster $\mathrm{B}_{1}$ includes A. mazandaranicum, A. hyrcanum, A. velutinum var. velutinum, $A$. velutinum var. glabrescens and sub-cluster $\mathrm{B}_{2}$ consists of A. monspessulanum subsp. microphyllum, A. monspessulanum subsp. cinerascens, A. monspessulanum subsp. assyriacum, A. monspessulanum subsp. persicum. two groups are showed in B1. Some characters such as wing margin hair, wing parallelism, wing angle, achene hair, can be distinguished their taxa. Also, subspecies of $A$. monspessulanum are showed in sub-cluster B2. Some characters such as wing surface hair, wing margin hair, achene hair density, wing angle, outside angle of wing, and inside angle of wing can be distinguished their taxa. Factor analysis and Principal Component Analysis (PCA) showed that wing surface hair, wing margin hair, achene hair, and achene hair density are the most variable and characters to separate the taxa (Figure 4).

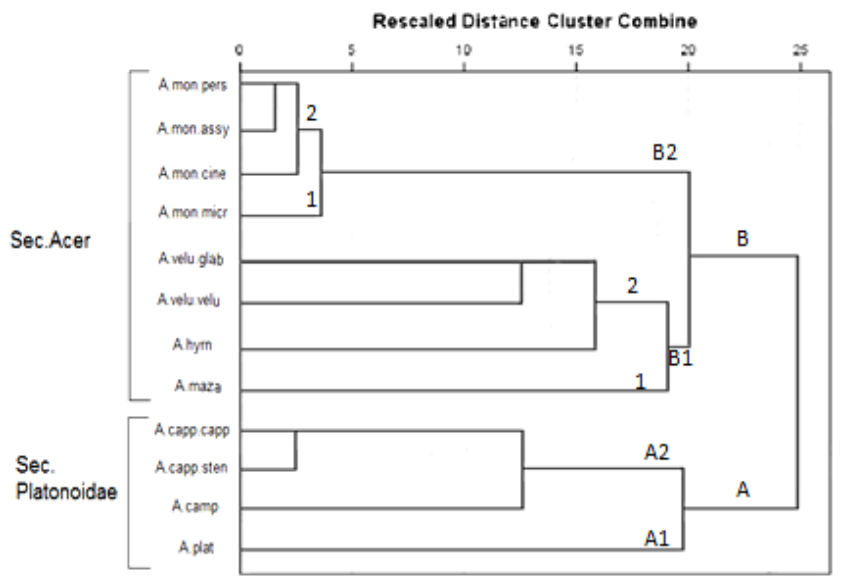

Figure 1. Cluster dendrogram of according to average linkage method based on qualitative and quantitative characteristics. Note: A mon pers $=A$. monspessulanum ssp. persicum, $\mathrm{A}$ mon assy $=A$. monspessulanum ssp. assyriacum, A mon cine $=A$. monspessulanum ssp. cinerascens, A mon micr $=A$. monspessulanum ssp. microphyllum, A vel glab $=A$. velutinum var. glabrescens, A hyr $=A$. hyrcanum, A maz $=A$. mazandaranicum, A capa capp $=A$. cappadocicum var. cappadocicum, A capp sten $=$ A. cappadocicum var. stenocarpum, A camp $=A$. campestre, A plat $=A$. platanoides

Table 1. List of studied taxa of Acer with localities and voucher numbers

\begin{tabular}{|c|c|c|c|c|c|}
\hline Specimen & Locality & Alt & No & $\mathbf{E}^{\mathbf{o}}$ & Voucher number \\
\hline A. campestre L. & Gilan, Talesh & 1250 & 48.81 & 37.82 & IAUNT-16110 \\
\hline A. hyrcanum Fisch. \& C.A.Mey. & Mazandaran, bisheband & 1740 & 52.40 & 36.13 & IAUNT-16113 \\
\hline A. mazandaranicum Amini, H.Zare \& Assadi & Gilan, Asalem to Khalkhal road & 900 & 48.65 & 37.58 & IAUNT-16112 \\
\hline A. cappadocicum var.cappadocicum & Ardabil, Gardane Heyran & 420 & 48.30 & 38.24 & IAUNT-16104 \\
\hline A. cappadocicum var. stenocarpum Yalt. & Gilan, lavandevill & 190 & 48.86 & 38.30 & IAUNT-16109 \\
\hline A. platanoides $\mathrm{L}$. & Gorgan, Paband & 2000 & 53.95 & 36.48 & IAUNT-16126 \\
\hline A. velutinum var. glabrescens (Boiss. \& Buhse) A. E. Murray & Ardabil, Hyran pass to Astara road & 850 & 38.27 & 48.39 & IAUNT-16101 \\
\hline A. velutinum var.velutinum & Tehran, Jamshidieh park & 1530 & 51.46 & 35.82 & IAUNT-16103 \\
\hline spessulanum subsp. persicum (Pojark.) Rech.f. & Kerman, Kushk & 2400 & 54.96 & 29.54 & IAUNT-16115 \\
\hline pessulanum subsp. microphyllum (Boiss.) Bornm. & Lorestan, Doroud & 2050 & 49.06 & 33.49 & IAUNT-16119 \\
\hline A. monspessulanum subsp. cinerascens (Boiss.) Yalt. & Lorestan, Doroud & 1850 & 49.07 & 33.50 & IAUNT-16117 \\
\hline A. monspessulanum subsp. assyriacum (Pojark.) Rech.f. & Lorestan, Khorramabad & 670 & 48.18 & 32.98 & IAUNT-16116 \\
\hline
\end{tabular}


Table 2. Fruit characters of studied taxa

\begin{tabular}{|c|c|c|c|c|c|c|c|c|c|c|c|c|c|c|c|c|c|c|c|c|c|}
\hline Specimen & SWC & WS & Wo & HWS & HWM & WP & WT & WA & SAO & AS & $\mathrm{AH}$ & HDA & $W L_{c m}$ & $\mathrm{WW}_{\mathrm{cm}}$ & WL/WW & $\mathrm{FL}_{\mathrm{cm}}$ & $\mathrm{FW}_{\mathrm{cm}}$ & FL/FW & $\begin{array}{l}\text { IAW } \\
\text { gradian }\end{array}$ & $\begin{array}{l}\text { OAW } \\
\text { gradian }\end{array}$ & $\begin{array}{l}\text { IAW/ } \\
\text { OAW }\end{array}$ \\
\hline A. campestre & 0 & 1 & 1 & 1 & 1 & 1 & 0 & 2 & 1 & 1 & 1 & 2 & 1.5 & 0.5 & 3 & 2 & 1.3 & 1.5 & 180 & 180 & 1 \\
\hline A. hyrcanum & 0 & 1 & 1 & 1 & 0 & 1 & 1 & 1 & 1 & 1 & 0 & 0 & 2.6 & 0.5 & 5.2 & 3.1 & 1.2 & 2.6 & 102 & 67 & 1.5 \\
\hline A. mazandaranicum & 0 & 1 & 1 & 1 & 1 & 0 & 1 & 2 & 1 & 1 & 1 & 2 & 1.5 & 1 & 1.5 & 2 & 1.5 & 1.3 & 20 & 10 & 2 \\
\hline A.cappadocicum var.cappadocicum & 1 & 0 & 1 & 1 & 1 & 1 & 1 & 1 & 1 & 1 & 1 & 2 & 1.6 & 0.6 & 2.6 & 2.2 & 1.2 & 1.8 & 103 & 86 & 1.4 \\
\hline A. cappadocicum var. stenocarpum & 0 & 1 & 1 & 1 & 1 & 1 & 1 & 1 & 0 & 1 & 1 & 2 & 2.2 & 0.9 & 2.4 & 3.1 & 2.2 & 1.4 & 123 & 86 & 1.4 \\
\hline A. platanoides & 1 & 1 & 0 & 1 & 1 & 1 & 1 & 1 & 1 & 0 & 1 & 2 & 1 & 0.5 & 2 & 1.8 & 1 & 1.8 & 100 & 50 & 2 \\
\hline A. velutinum var. glabrescens & 1 & 0 & 1 & 0 & 0 & 1 & 1 & 1 & 1 & 1 & 0 & 0 & 4 & 0.8 & 5 & 4.5 & 1.6 & 2.8 & 108 & 63 & 1.7 \\
\hline A.velutinum var.velutinum & 1 & 1 & 0 & 0 & 0 & 1 & 1 & 1 & 1 & 1 & 0 & 1 & 2 & 0.5 & 4 & 2.4 & 1 & 2.4 & 112 & 68 & 1.6 \\
\hline A. monspessulanum subsp. persicum & 0 & 1 & 1 & 1 & 1 & 0 & 1 & 2 & 1 & 1 & 1 & 2 & 1 & 0.5 & 2 & 1.5 & 1 & 1.5 & 40 & 10 & 4 \\
\hline A. monspessulanum subsp. microphyllum & 0 & 1 & 1 & 0 & 0 & 1 & 1 & 0 & 1 & 0 & 0 & 0 & 1.2 & 0.3 & 4 & 1.5 & 0.5 & 3 & 60 & 25 & 2.4 \\
\hline A. monspessulanum ssp. cinerascens & 0 & 1 & 1 & 1 & 1 & 1 & 1 & 0 & 1 & 0 & 1 & 2 & 1.7 & 0.4 & 4.2 & 2.2 & 1 & 2.2 & 67.5 & 25 & 2.7 \\
\hline A. monspessulanum ssp. assyriacum & 0 & 1 & 1 & 1 & 1 & 1 & 1 & 0 & 1 & 1 & 1 & 2 & 2 & 0.5 & 4 & 3 & 1.5 & 2 & 80 & 50 & 1.6 \\
\hline
\end{tabular}



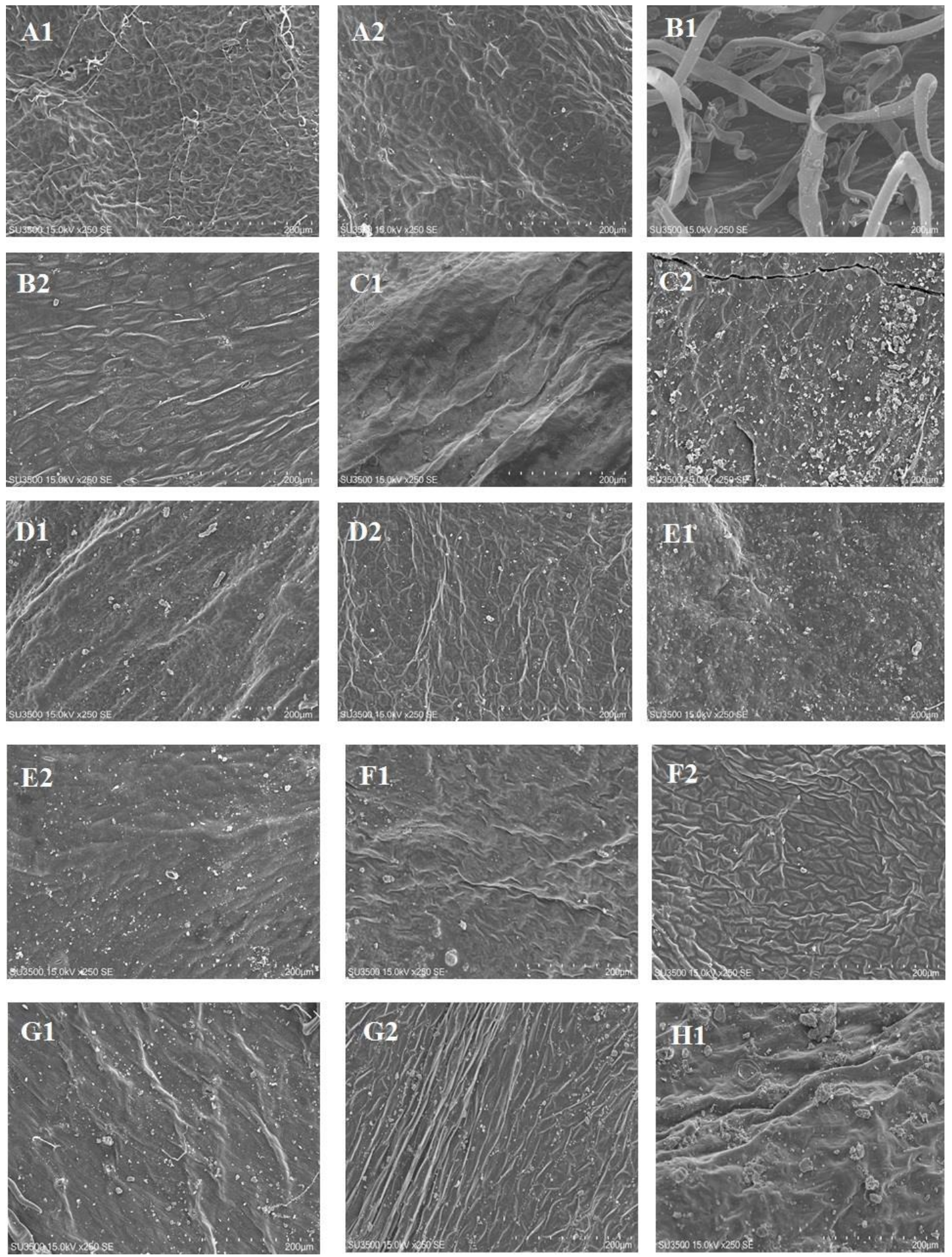

Figure 2. SEM photographs show fruit morphology of the studied species of genus Acer L. The first photographs represent the surface ornamentation of the achene and the second ones show the details of the surface ornamentation of the wing. A1-A2: A. campestre; B1B2: A. hyrcanum; C1-C2: A. mazandaranicum; D1-D2: A. cappadocicum var. cappadocicum; E1-E2: A. cappadocicum var. stenocarpum; F1-F2: A. platanoides; G1-G2: A. velutinum var. glabrescens; H1: A.velutinum var.velutinum

The science of micromorphology is important sometimes for the definition and classification of taxa and their relation to certain groups studies on plants enable micro-level analysis of pollen, leaves, fruit, epidermal patterns, tissues, seeds, etc. of plants via scanning electron microscope. Acer is a genus which is taxonomically diverse due to differences in leaf shape, inflorescence structure, and other morphological characteristics (Delendick 1990). Determination of the limits of Acer species is difficult due to differences are fine and continuous. According to the results from pollen morphology (Nikzat Siahkolahi et al. 2017), the varieties 
of A. velutinum overlapped and the result practically pollen morphology could not be applied in the separation of these two varieties. In this work, the morphology of fruits, showed that these two taxa are separated at higher taxonomic level than variety. Varieties of A. velutinum var. velutinum, and $A$. velutinum var. glabrescens were totally separated due to differences in characteristics such as achene ornamentation (SAO), hair density of achene (HAD), wing length (WL), wing width (WW), the ratio of length to width of wing (WL/WW), inside angle of wing (IAW), outside angle of wing (OAW) (investigated traits in table 3) and this result complied with molecular results obtained for the two varieties of the mentioned species (Asadi et al. not published yet).
Due to similarities between $A$. hyrcanum and $A$. mazandaranicum, there is a necessity to revising their taxonomic positions and considering the possibility that they belong to one taxon. Micro-morphological study of leaf by Mohtashamian et al. in 2017 showed that the structure and shape of epidermis cannot separate $A$. mazandaranicum and $A$. hyrcanum as two species. Therefore, it can be concluded that these two species are very close and A. mazandaranicum may be similar to $A$. hyrcanum. But, in this work, the two species were separated due to differences in fruit morphology characters such as hair of margin, wing parallelism, wing angle, achene hair, etc (Table 4).
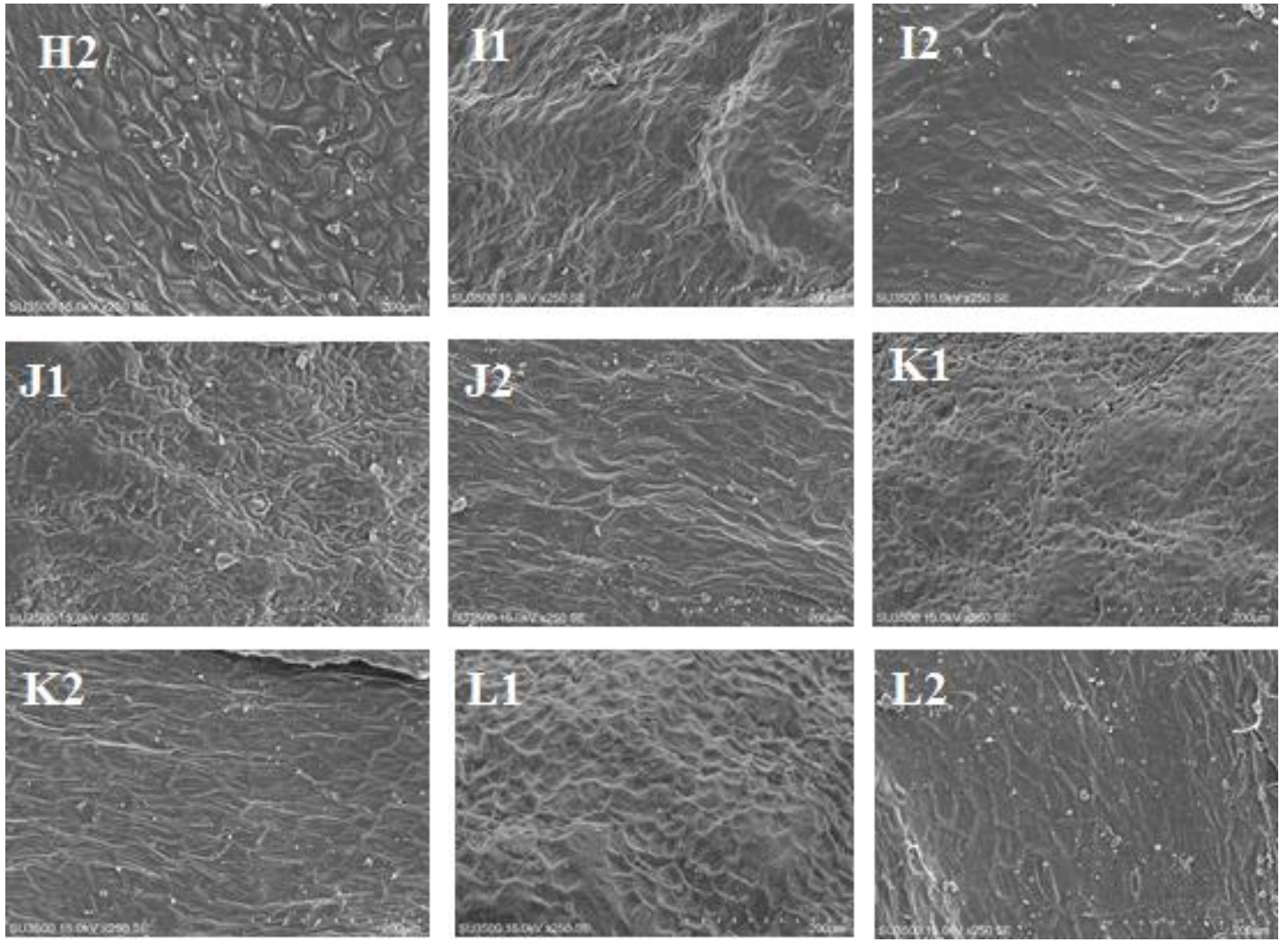

Figure 3. SEM photographs show fruit morphology of the studied species of genus Acer L. The first photographs represent the surface ornamentation of the achene and the second ones show the details of the surface ornamentation of the wing. H2: A. velutinum var. velutinum; I1-I2: A. monspessulanum subsp. persicum; J1-J2: A. monspessulanum subsp. microphyllum; K1-K2: A. monspessulanum subsp. cinerascens; L1-L2: A. monspessulanum subsp. assyriacum

Table 3. Separating characteristics of A. velutinum var. velutinum and A. velutinum var. glabrescens

\begin{tabular}{lccccccccccc}
\hline \multicolumn{1}{c}{ Specimen } & WS & WO & HDA & $\mathbf{W L}_{\mathbf{c m}}$ & $\mathbf{W W}_{\mathbf{c m}}$ & $\mathbf{W L} / \mathbf{W W}$ & $\mathbf{F L}_{\mathbf{c m}}$ & $\mathbf{F W}_{\mathbf{c m}}$ & FL/FW & $\begin{array}{c}\text { IAW } \\
\text { gradian }\end{array}$ & $\begin{array}{c}\text { OAW } \\
\text { gradian }\end{array}$ \\
\hline $\begin{array}{l}\text { A. velutinum var. glabrescens } \\
\text { A.velutinum var.velutinum }\end{array}$ & 0 & 1 & 0 & 4 & 0.8 & 5 & 4.5 & 1.6 & 2.8 & 108 & 63 \\
\hline
\end{tabular}

WS: Wing surface, WO: Wing ornamentation, HDA: Hair density of achene, WL: Wing Length, WW: Wing Width, WW/WL: Ratio of wing width to wing length, FL: Fruit length, FW: Fruit width, FW/FL: Ratio of fruit width to fruit length, IAW: Inside angle of the wing, OAW: Outside angle of the wing 
Table 4. separating characteristics of A. mazandaranicum and A. hyrcanum

\begin{tabular}{|c|c|c|c|c|c|c|c|c|c|c|c|c|c|c|}
\hline Specimens & HWM & WP & WA & $\mathbf{A H}$ & HDA & $\begin{array}{l}\text { WL } \\
\text { cm }\end{array}$ & $\begin{array}{l}\text { WW } \\
\text { cm }\end{array}$ & WL/WW & $\begin{array}{l}\text { FL } \\
\text { cm }\end{array}$ & $\begin{array}{l}\text { FW } \\
\text { cm }\end{array}$ & FL/FW & $\begin{array}{c}\text { IAW } \\
\text { gradian }\end{array}$ & $\begin{array}{c}\text { OAW } \\
\text { gradian }\end{array}$ & $\begin{array}{l}\text { IAW/ } \\
\text { OAW }\end{array}$ \\
\hline A. hyrcanum & 0 & 1 & 1 & 0 & 0 & 2.6 & 0.5 & 5.2 & 3.1 & 1.2 & 2.6 & 102 & 67 & 1.5 \\
\hline A. mazandaranicum & 1 & 0 & 2 & 1 & 2 & 1.5 & 1 & 1.5 & 2 & 1.5 & 1.3 & 20 & 0 & 2 \\
\hline
\end{tabular}

Note: HWM: Hair of wing margin, WP: Wing parallelism, WA: Wing angle, AH: Achene hair, HDA: Hair density of achene, WL: Wing Length, WW: Wing Width, WL/WW: Ratio of wing length to wing width, FL: Fruit length, FW: Fruit width, FL/FW: Ratio of fruit length to fruit width, IAW: Inside angle of the wing, OAW: Outside angle of the wing, IAW/OAW: Ratio of Inside angle of the wing to outside angle of the wing.

Table 5. Separating characteristics of subspecies of A. monspessulanum

\begin{tabular}{lccccccccccccc}
\hline Specimen & HWS & HWM & WP & WA & AS & AH & HDA & $\begin{array}{c}\text { WL } \\
\text { cm }\end{array}$ & WL/WW & $\begin{array}{c}\text { FL } \\
\text { cm }\end{array}$ & $\begin{array}{c}\text { IAW } \\
\text { gradian }\end{array}$ & $\begin{array}{c}\text { OAW } \\
\text { gradian }\end{array}$ & $\begin{array}{c}\text { IAW/ } \\
\text { OAW }\end{array}$ \\
\hline A. monspessulanum subsp. persicum & 1 & 1 & 0 & 2 & 1 & 1 & 2 & 1 & 2 & 1.5 & 40 & 10 & 4 \\
A. monspessulanum subsp. microphyllum & 0 & 0 & 1 & 0 & 0 & 0 & 0 & 1.2 & 4 & 1.5 & 60 & 25 & 2.4 \\
A. monspessulanum subsp. cinerascens & 1 & 1 & 1 & 0 & 0 & 1 & 2 & 1.7 & 4.2 & 2.2 & 67.5 & 25 & 2.7 \\
A.monspessulanum subsp.assyriacum & 1 & 1 & 1 & 0 & 1 & 1 & 2 & 2 & 4 & 3 & 80 & 50 & 1.6 \\
\hline
\end{tabular}

Note: HWS: Hair of wing surface, HWM: Hair of wing margin, WP: Wing parallelism, surface, AH: Achene hair, HDA: Hair density of achene, WL: Wing Length, WL/WW: Ratio of wing length to wing width, FL: Fruit length, IAW: Inside angle of the wing, OAW: Outside angle of the wing, IAW/OAW: Ratio of Inside angle of the wing to outside angle of the wing.

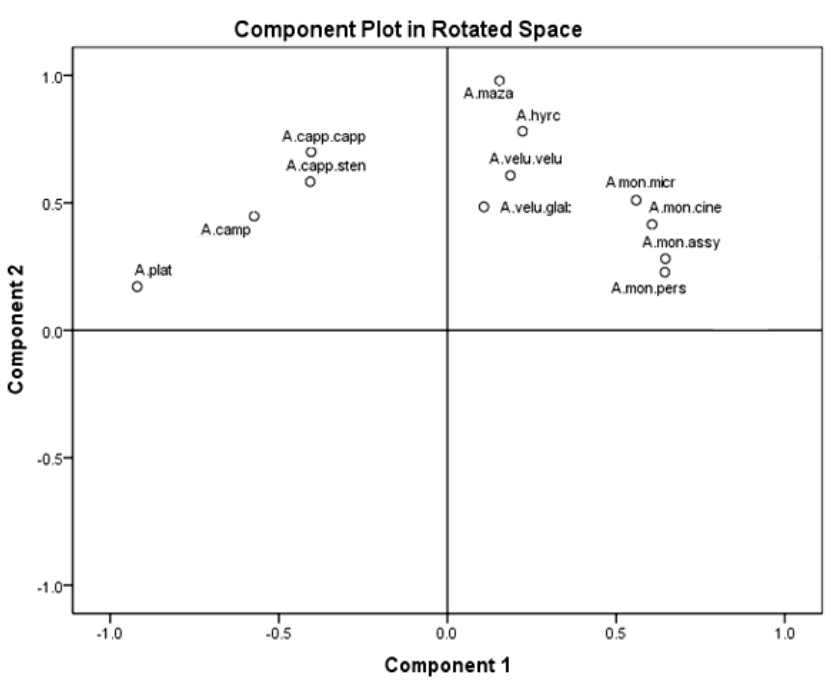

Figure 4. PCA plot of fruit characters

Four subspecies of Acer monspessulanum are very similar together. Khademi et al., 2016 was reported presence or lack of hair on the surface or inside achene are diagnostic features for subspecies level. In this work, micromorphological characters are used for separation of A. monspessulanum (A. subsp. microphyllum, A. subsp. assyriacum, $A$. subsp. cinerascens, and $A$. subsp. persicum) which have always been hard to distinguish. Except for subsp. microphyllum, other subspecies are native to Iran and among them subsp. persicum is endemic (Amini et al 2008) Micromorphological characteristics of fruit showed that the presence or lack of hair on wing margin (HWM), presence or lack of hair on wing surface (HWS), wing angle (WA), achene hair (AH), inside angle of wing
(IAW), outside angle of wing (OAW), and the ratio of inside angle to outside angle of wing (IAW/OAW) (investigated traits in Table 5) which can separate four subspecies of this species.

In this work, micro-macromorphological characteristics of fruit especially wing ornamentation, hair of wing, hair of achene was found to be very useful for the separation of taxa in Acer genus even at subspecies and varieties level.

\section{ACKNOWLEDGEMENTS}

The authors wish to thank Saeed Javadi Anaghizi in the central laboratory of the Shahid Beheshti University, Tehran, Iran for providing SEM pictures.

\section{REFERENCES}

Acevedo-Rodríguez P, Van Welzen PC, Adema F, Van der Ham RWJM. 2011. Sapindaceae. In: Kubitzki K. (ed.) The Families and Genera of Vascular Plants vol. X: Flowering Plants. Eudicots: Sapindales, Cucurbitales, Myrtaceae. Springer-Verlag, Berlin.

Amini T, Zare H, Assadi M. 2008. Acer mazandaranicum (Aceraceae), a new species from northern Iran. Iran J Bot 14 (2): 81-86.

Bani B, Karakaya MA, Çeter T. 2016. Fruit micromorphological characters of the genus Grammosciadium DC. (Apiaceae) in Turkey. Phytotaxa 246 (2): 184-191.

Buerki S, Forest F, Acevedo-Rodríguez P, Callmander MW, Nylander JAA, Harrington M, Sanmartín I, Küpfer P, Alvarez N. 2009. Plastid and nuclear DNA markers reveal intricate relationships at sub-familial and tribal levels in the Soapberry family (Sapindaceae). Mol Phylogenet Evol 51 (2): 238-258.

De Jong PC. 191976. Flowering and sex expression in Acer L. A biosystematic study, thesis, University of Wageningen, Netherland

De Jong PC. 1994. Taxonomy and reproductive biology of maples. Timber Press, Portland, USA. 
Delendick TJ. 1982. A systematic review of the Aceraceae. [Dissertation]. University of New York, New York.

Delendick TJ. 1990. A survey of foliar flavonoids in the Aceraceae. Mem New York Bot Gard 54: 1-129.

Fang WP. 1966. Revision Taxorum Aceracearum Sinicarum. Acta Phytotaxonomica Sinica 11: 139-189.

Fang WP. 1981. Aceraceae. In: Fang WP. (ed.) Flora Republicae Popularis Sinicae 46: 66-273.

Fontaine C. 2011. Fleurs De France (French ed), Nabu Press, French.

Gran A, Sharifnia F. 2008. Miro-macromorphological studies of the genus Glaucium (Papaveraceae) in Iran. Iranian J Bot14 (127): 23-38.

Grimm GW, Denk T, Hemleben V. 2007. Evolutionary history and systematics of Acer section Acer a case study of low-level phylogenetics. Plant Syst Evol 267: 215-253.

Grimm GW, Denk T. 2014. The Colchic region as refuge for relict tree lineages: cryptic speciation in field maples. Turk J Bot 38 (6): 10501066.

Hasebe M, Ando T, Iwatsuki K. 1998. Intrageneric relationships of maple trees based on the chloroplast DNA restriction fragment length polymorphisms. J Plant Res 111 (3): 441-451.

Huang SF, Ricklefs RE, Raven PH. 2002. Phylogeny and historical biogeography of Acer: 1. Study history of the infrageneric classification. Taiwania 47 (3): 203-218.

Judd WS, Campbell CS, Kellogg EA, Donoghue MJ. 2002. Plant Systematics: A Phylogenetic Approach, 2nd ed. Sinauer, Sunderland.

Khademi M, Mehregan I, Nejadsattari T, Zarre S. 2016. Molecular phylogeny of Acer monspessulanum L. subspecies from Iran inferred using the ITS region of nuclear ribosomal DNA, Biodiversitas 17 (1): 16-23.

Kholie DK. 1967. Les chênes de. L'Iran. [Dissertation]. Universite de Montpellier, Montpellier, France [France]

Kvacek Z, Velitzelos D, Velitzelos E. 2002. Late Miocene Flora of Vegora, Macedonia, $\mathrm{N}$ Greece. University of Athens, Athens.

Maroofi H, Sharifi K. 2006. Acer tataricum (Aceraceae), a new collection from W. of Iran. Iranian J Bot 12 (1): 57-58.

Mohtashamian M, Attar F, Kavousi K, Masoudi-Nejad A. 2017 Micromorphological studies of leaf epidermal features in populations of Maples (Acer L.) from Iran. Phytotaxa 299 (1): 36-54.

Momotani Y. 1962. Taxonomic study of the genus Acer with special reference to the seed proteins. III. System of Aceraceae. Memoirs of the College of Science, Kyoto Imperial University, Series B 29: 177189.

Murray AE. 191969. Aceraceae. In: Rechinger KH (ed.). Flora Iranica, no 61. Graz 11

Murray AE. 1970. A Monograph of the Aceraceae. [Dissertation]. State College, Pennsylvania State University, State College, PA.

Murray AE. 1980. Aceraceae. In: Ali SI (ed.). Flora of Pakistan. Pakistan Agricultural Research Council, Islamabad.

Nikzat Siahkolaee S, Sheidai M, Assadi M, Noormohammadi Z. 2017 Pollen morphological diversity in the genus Acer L. (Sapindaceae) in Iran, Acta Biologica Szegediensis 61 (1): 95-104.

Ogata K. 191967. A systematic study of the genus Acer. Bull Tokyo Univ Forests 63: 89-206.
Park CW, Oh S, Shin H. 1993. Reexamination of vascular plants in Ullung Island, Korea II: Taxonomic identity of Acer takeshimense Nakai (Aceraceae). Korean J Pl Taxon 23: 217-231.

Pax F. 1885. Monograph der Gattung Acer. Bot Jahrb 6: 287-347.

Pax F. 1902. Aceraceae. In: Engler HGA. (ed.) Das Pflanzenreich IV, 163. Verlag Engelmann, Leipzig, Germany.

Podani J. 2000. Introduction to the Exploration of Multivariate Biological Data [English translation]. Backhuys Publishers, Leiden.

Pojarkova AI. 1933. Botanico-geographical survey of the maples of the USSR, in connection with the history of the whole genus. Trudy Botanicheskogo Instituta Akademii Nauk SSSR. Ser. 1. Flora i Sistematika Vyssikh Rastenii 1: 225-374.

Pojarkova AI. 1949. Aceraceae. In: Shishkin BK, Bobrov EG (eds.) Flora of the U.S.S.R (English translation), vol. XIV: Geraniales, Sapindales, Rhamnales. Israel Program for Scientific Translation Jerusalem.

Rushforth KD. 1999. Trees of Britain and Europe. HarperCollins, London. Sachse M. 2004. Die Neogene Mega-und Mikro-flora von Makrilia auf Kreta und ihre Aussagen zur Klima-und Vegetationsgeschichte des o"stlichen Mittelmeergebietes. Flora Tertiaria Mediterranea 6: 1323.

Sachse M. 2004. Die Neogene Mega-und Mikro-flora von Makrilia auf Kreta und ihre Aussagen zur Klima-und Vegetationsgeschichte des o"stlichen Mittelmeergebietes. Flora Tertiaria Mediterranea 6: 1-323.

Sharifnia, F, Heydarian, S, Salimpour, F. 2010. Biosystematic study of some Papaver (Papaveraceae) species from Iran, Iranian J Bot 169131: 54-68.

Sharifnia, F, Behzadi Shakib, S. 2012. Epidermal petal pattern of 13 Iranian Rubus L. (Rosaceae)species, Ann Biol Res 3: 2734-2740.

Simpson, MG. 2010. Plant Systematics. 2nd ed. Academic Press, Amsterdam.

Tanai T. 1978. Taxonomical investigation of the living species of the genus Acer L., based on vein architecture of leaves. J Fac Sci Hokkaido Univ Ser 4 Geol Mineral 18 (3): 243-282.

van Gelderen DM, de Jong PC, Oterdoom HJ. 1994. Maple of the World. Timber Press, Portland, Oregon.

van Gelderen CJ, van Gelderen DM. 1999. Maples for Gardens: A Color Encyclopedia. Timber Press, Inc., Portland.

Van Gelderen DM, De Jong PC, Oterdoom HJ. 2010. Maple of the World. Timber Press, Portland, Oregon.

Weakley AS. 2011. Flora of the Southern and Mid-Atlantic States. University of North Carolina Herbarium, North Carolina Botanical Garden, University of North Carolina, Chapel Hill, USA.

Xu T. 1966. A new system of Acer. Acta Bot Yunnan 18: 277-292.

Xu T. 1998. The systematic evolution and distribution of the genus Acer. Acta Bot Yunnan 20: 383-393.

$\mathrm{Xu}$ T, Chen Y-S, De Jong PC, Oterdoom HJ, Chang C-S. 2008. Aceraceae. In: Wu ZY, Raven PH, Hong DY (eds). Flora of China Vol 11 (Oxalidaceae through Aceraceae). Missouri Botanical Garden Press, St. Louis, USA.

Yaltirik F. 1967. Aceraceae. In: Davis PH. (ed.) Flora of Turkey and the East Aegean Islands, vol. 2. Edinburgh, UK 